\title{
IN VITRO ASSESSMENT OF AN EXPERIMENTAL COAT APPLIED OVER FLUORIDE VARNISHES
}

\author{
Alberto Carlos Botazzo DELBEM ${ }^{1}$, Fernanda Lourenção BRIGHENTI ${ }^{2}$, Felipe Alberto Lino OLIVEIRA ${ }^{3}$, Juliano Pelin PESSAN ${ }^{2}$, \\ Marília Afonso Rabelo BUZALAF ${ }^{4}$, Kikue Takebayashi SASSAKI ${ }^{1}$
}

\author{
1- DDS, MSc, PhD, Professor, Araçatuba Dental School, São Paulo State University, Araçatuba, SP, Brazil. \\ 2- DDS, MSc, PhD, Former Graduate Student, Araçatuba Dental School, São Paulo State University, Araçatuba, SP, Brazil. \\ 3- DDS, Former Undergraduate Student, Araçatuba Dental School, São Paulo State University, Araçatuba, SP, Brazil. \\ 4- DDS, MSc, PhD, Professor, Department of Biological Sciences, Bauru School of Dentistry, University of São Paulo, Bauru, SP, Brazil.
}

Corresponding address: Prof. Dr. Alberto Carlos Botazzo Delbem - Rua José Bonifácio 1193, 16015-050 Araçatuba, SP, Brasil - Phone: +55-18-3636-

3235. email: adelbem@foa.unesp.br

Received: July 06, 2008 - Modification: October 09, 2008 - Accepted: November 09, 2008

\begin{abstract}
$O$

bjective: The time of contact between the product and enamel surface is important in ensuring the efficacy of fluoride varnishes. Thus, some alternatives could avoid fluoride loss to saliva and improve the anticariogenic action of the product. This study evaluated the effect of an experimental coat on the anticariogenic action of fluoride varnishes. Material and Methods: Enamel bovine blocks were selected by evaluating surface microhardness and randomized into five groups $(n=24)$ : placebo, Duraphat ${ }^{\mathrm{TM}}$, Duraphat ${ }^{\mathrm{TM}}$ with coat, Duofluorid ${ }^{\mathrm{TM}}$ and Duofluorid ${ }^{\mathrm{TM}}$ with coat. Twelve blocks from each group were used to analyze calcium fluoride $\left(\mathrm{CaF}_{2}\right)$ formed on enamel after treatment. The other 12 blocks were subjected to $\mathrm{pH}$ cycling for 7 days. The varnishes were kept on enamel for $6 \mathrm{~h}$. Next, the percentage change of surface microhardness (\%SMHC) and mineral loss $(\Delta \mathrm{Z})$ were calculated. $\mathrm{CaF}_{2}$ retained and fluoride present in the $\mathrm{pH}$-cycled solutions were also measured. Results: The use of the coat did not decrease $\% \mathrm{SMHC}$ and $\Delta \mathrm{Z}$, but all fluoride varnishes had better results when compared to the placebo (ANOVA and Kruskal-Wallis, respectively). The values from $\mathrm{CaF}_{2}$ formed were higher compared to the values of $\mathrm{CaF}_{2}$ retained (non-paired test, $\mathrm{p}<0.05$ ). There was a trend to decrease the amount of $\mathrm{F}$ in the solutions at the end of $\mathrm{pH}$ cycling (Kruskal-Wallis, $\mathrm{p}<0.05$ ). Conclusions: Although the experimental coat increased the formation of $\mathrm{CaF}_{2}$ on the enamel surface, it did not significantly improve the anticariogenic action of fluoride varnishes.
\end{abstract}

Key words: Dental caries, prevention \& control. Topical fluorides.

\section{INTRODUCTION}

The effectiveness of fluoride $(\mathrm{F})$ varnishes has been well established in caries prevention studies involving permanent teeth ${ }^{11}$. Clinical studies have demonstrated a decline of caries incidence from 18 up to $70 \%{ }^{15}$. F varnishes are easy to apply, safe, and well accepted by patients ${ }^{3}$. Therefore, the use of $\mathrm{F}$ varnishes has been recommended for children at high or moderate risk to develop dental caries ${ }^{21}$. Moreover, it is the only product recommended for children up to 6 years of age who have special health care needs ${ }^{17}$.

Fluoride varnishes modify the physiochemical properties of teeth, enhancing remineralization and inhibiting demineralization ${ }^{10}$. Recently, the decrease in $S$. mutans counts after $\mathrm{F}$ varnish application has also been reported ${ }^{12}$ Fluoride varnishes are viscous products that harden in contact to saliva. They adhere to the teeth and enhance $\mathrm{F}$ release to the enamel surface, dental plaque and saliva. This adhesion also enables the application in small amounts, decreasing the risk of $\mathrm{F}$ over-ingestion ${ }^{23}$.

A previous work from our research group showed differences on anticariogenic action and calcium fluoride $\left(\mathrm{CaF}_{2}\right)$ formation in seven marketed varnishes available in Brazil as a result of variations on physical properties of $F$ varnishes ${ }^{14}$.

Physical properties can influence the activity of $\mathrm{F}$ varnishes on enamel surface. Considering that the contact time between the fluoride product and the enamel surface is very important to the efficacy of this preventive measure ${ }^{23}$, the use of some materials could avoid F loss to saliva and, consequently, improve its anticariogenic effect. The aim of this study was to evaluate the effect of an experimental coat on the anticariogenic action of fluoride varnishes.

\section{MATERIALS AND METHODS}

\section{Experimental Groups}

Two market varnishes were used: Duraphat $5 \%$ NaF, A. Nattterman \& Cie. GmbH., Colony, Germany) and Duofluorid XIITM ("Duo"; $6 \% \mathrm{NaF}$ and $6 \% \mathrm{CaF}_{2}$, Dentscare Ltda, Joinville, SC, Brazil). The experimental coat 
was supplied by FGM Dental Products. The coat has the same composition as that of Duofluorid XIITM (Dentscare Ltda, Joinville, SC, Brazil) but does not contain fluoride. The coat was applied over the fluoride varnishes, as a second layer, and was also used in the placebo group (negative control).

\section{pH-cycling and Treatment with $F$ varnishes}

Enamel blocks $(4 \times 4 \mathrm{~mm})$ were obtained from bovine incisors previously stored in a $2 \%$ formaldehyde solution at $\mathrm{pH} 7.0$ for 30 days at room temperature ${ }^{24}$. The enamel surfaces were serially polished and the blocks were selected based on the surface microhardness (SMH) (324.8 up to $357.0 \mathrm{KHN})$ and were randomized into five groups $(\mathrm{n}=12)$ : a) coat only ("placebo"; varnish without fluoride), b) Dura, c) Dura with the experimental coat (Dura + coat), d) Duo and e) Duo with the experimental coat (Duo + coat).

The blocks were subjected to seven days of a $\mathrm{pH}$-cycling model based on Vieira, et al. ${ }^{24}$. Initially, the enamel was treated with the varnishes and coat, if applicable, and placed in a demineralizing solution ("DE": $2.0 \mathrm{mmol} \mathrm{L} \mathrm{m}^{-1}$ calcium and phosphate in $75 \mathrm{mmol} \mathrm{L}^{-1}$ acetate buffer, $\mathrm{pH} 4.7 ; 0.04$ $\mu \mathrm{g} \mathrm{F} / \mathrm{mL}, 2.2 \mathrm{~mL} / \mathrm{mm}^{2}$ ). After $6 \mathrm{~h}$, the varnishes were removed with a blade and acetone ${ }^{5}$ and the blocks were transferred to a remineralizing solution ("RE": $1.5 \mathrm{mmol} \mathrm{L}^{-1}$ calcium, 0.9 mmol L-1 phosphate, $150 \mathrm{mmol} \mathrm{L}^{-1} \mathrm{KCl}$ in $0.1 \mathrm{~mol} \mathrm{~L}^{-1}$ cacodylic buffer, pH 7.0; $0.05 \mathrm{mg} \mathrm{F} / \mathrm{mL}, 1.1 \mathrm{~mL} / \mathrm{mm}^{2}$ ) for $18 \mathrm{~h}$. On the second day, both solutions were changed due to $F$ release from the varnishes. These solutions were kept until the $5^{\text {th }}$ day. During the $6^{\text {th }}$ and the $7^{\text {th }}$ day, the enamel blocks were kept in the remineralizing solution.

After $\mathrm{pH}$ cycling, aliquots of the solutions were mixed with TISAB II (total ionic strength adjustment buffer) at 1:1 TISAB II:sample ratio ( $\mathrm{pH} 5.2$ ) and the amount of $\mathrm{F}$ in the solutions was analyzed, using an ion-selective electrode (Orion 96-09; Orion Research Inc., Beverly, MA, USA) and a digital ion analyzer (Orion 720A; Orion Research Inc.),

\section{Microhardness Analysis}

Surface (SMH) and cross-sectional (CSMH) microhardness measurements were made on enamel surface as described before ${ }^{24}$, except for the fact that the load used was $25 \mathrm{~g}$. The \%SMHC was calculated. Next, the blocks were bisected and CSMH was performed. The CSMH values were converted to mineral content by volume, according to Featherstone, et al. ${ }^{9}$. The integrated mineral loss $(\Delta \mathrm{Z})$ after $\mathrm{pH}$ cycling was calculated ${ }^{1,18}$.

\section{Calcium Fluoride $\left(\mathrm{CaF}_{2}\right)$ Analysis}

The loosely-bound fluoride $\left(\mathrm{CaF}_{2}\right)$ was analyzed to evaluate the amount of $\mathrm{CaF}_{2}$ present after fluoride varnish application $\left(\mathrm{CaF}_{2}\right.$ formed) or to analyze the amount of $\mathrm{CaF}_{2}$ that was still adsorbed to the enamel after $\mathrm{pH}$-cycling $\left(\mathrm{CaF}_{2}\right.$ retained). In order to assess $\mathrm{CaF}_{2}$ formed, 12 blocks from each group were treated as described above, but were subjected to only one $24 \mathrm{~h}$ cycle. The analysis of $\mathrm{CaF}_{2}$ retained was done in the $\mathrm{pH}$-cycled blocks. The enamel blocks were immersed in $0.5 \mathrm{~mL} \mathrm{KOH} 1 \mathrm{~mol} \mathrm{~L}^{-1}$ for $24 \mathrm{~h}$ under agitation. Next, the same volume of TISAB II with $\mathrm{HCl}(8.2 \mathrm{~mL} / \mathrm{L})$ was added ${ }^{6}$. The final $\mathrm{pH}$ of the solutions was 5.2.

Fluoride measurement was performed with an ionselective electrode Orion 96-09 (Orion Research Inc.) and an ion analyzer Orion $720 \mathrm{~A}+$ (Orion Research Inc.), calibrated with standards containing 0.0625 up to $2.0 \mu \mathrm{g} \mathrm{F} /$ $\mathrm{mL}$. The results were expressed as $\mu \mathrm{g} F / \mathrm{cm}^{2}$.

\section{Statistical Analysis}

The null hypothesis tested was that the use of the experimental coat does not improve the anticariogenic action of fluoride varnishes. GMC software was used for statistical analysis. First, normality and homogeneity of data was determined. Data from $\Delta \mathrm{Z}, \mathrm{CaF}_{2}$ formed, $\mathrm{CaF}_{2}$ retained and $\mathrm{F}$ present in solutions were not normal and had a nonhomogeneous distribution. Thus, Kruskal-Wallis test was used at each data point. For $\% \mathrm{SMHC}$, each data point was tested with one-way ANOVA. The difference between $\mathrm{CaF}_{2}$ formed and $\mathrm{CaF}_{2}$ retained was evaluated with the non-paired $t$ test. The significance level was set at $5 \%$ for all analyses.

\section{RESULTS}

Table 1 shows that the application of the coat was not able to improve either \%SMHC or $\Delta \mathrm{Z}$. Moreover, when comparing the varnishes, there were no differences on surface demineralization (\%SMHC) but the lesion depth $(\Delta \mathrm{Z})$ for the groups treated with Duo was shallower when compared to the groups treated with Dura (Table 1).

In addition, the presence of the coat allowed greater formation of $\mathrm{CaF}_{2}$-like material for Duo+coat, but not for Dura+coat, when compared to the respective commercial varnishes without the coat. Greater retention of $\mathrm{CaF}_{2}$ was observed for both varnishes associated with the coat. For all treatment groups, except for placebo, there were significantly lower $\mathrm{CaF}_{2}$ retained than $\mathrm{CaF}_{2}$ formed (Table 1).

F release to the solutions DE1, RE1 and DE2 was different in all treatment groups. Furthermore, the groups treated with Duo showed higher amount of $\mathrm{F}$ in the $\mathrm{pH}-$ cycling solutions. The presence of the coat decreased $\mathrm{F}$ release in DE1. On the other hand, after the coat was removed, the groups Duo+coat and Dura+coat presented the highest amount of F in the solutions RE1 and DE2. In the last 2 days of $\mathrm{pH}$-cycling, the groups Duo and Duo+coat showed higher amount of F in RE2 when compared to Dura or Dura+coat, regardless of whether the coat was applied or not (Table 2).

\section{DISCUSSION}

Calcium fluoride is the main product formed after the application of a topical fluoride, especially with highly concentrated $\mathrm{F}$ products. The amount of $\mathrm{CaF}_{2}$ formed depends on the $\mathrm{pH}$, the duration of exposure and the $\mathrm{F}$ 
TABLE 1- Results of percentage change of surface microhardness (\%SMHC), mineral loss $(\Delta \mathrm{Z}), \mathrm{CaF}_{2}$ formed and $\mathrm{CaF}_{2}$ retained $\left(\mu \mathrm{g} \mathrm{F} / \mathrm{cm}^{2}\right)$. Mean \pm standard error, $\mathrm{n}=12$

\begin{tabular}{|c|c|c|c|c|}
\hline Group & $\% \mathrm{SMHC}^{*, \neq}$ & $\Delta \mathbf{Z}^{*}$, & $\mathrm{CaF}_{2}$ formed $^{\star}, \mathrm{s} \S$ & $\mathrm{CaF}_{2}$ retained ${ }^{\star},+, \S$ \\
\hline Placebo & $-74.6 \pm 9.6^{a}$ & $1535.6 \pm 210.6^{a}$ & ${ }^{\mathrm{A}} 0.3 \pm 0.0^{\mathrm{a}}$ & ${ }^{\mathrm{B}} 0.6 \pm 0.0^{\mathrm{a}}$ \\
\hline Dura & $-36.1 \pm 4.8^{b}$ & $887.0 \pm 660.8^{b}$ & ${ }^{A} 2.9 \pm 0.2^{b}$ & ${ }^{\mathrm{B}} 0.9 \pm 0.1^{\mathrm{b}}$ \\
\hline Dura+coat & $-35.6 \pm 6.3^{b}$ & $1007.8 \pm 540.7^{b}$ & ${ }^{A} 3.4 \pm 0.3^{b}$ & ${ }^{\mathrm{B}} 1.2 \pm 0.1^{\mathrm{c}}$ \\
\hline Duo & $-36.3 \pm 3.7^{b}$ & $470.0 \pm 189.8^{c}$ & $\mathrm{~A} 11.8 \pm 1.0^{\mathrm{C}}$ & ${ }^{\mathrm{B}} 2.4 \pm 0.3^{\mathrm{d}}$ \\
\hline Duo+coat & $-37.5 \pm 7.4^{b}$ & $377.9 \pm 160.6^{c}$ & ${ }^{A} 26.1 \pm 1.5^{d}$ & ${ }^{\mathrm{B}} 4.4 \pm 0.5^{\mathrm{e}}$ \\
\hline
\end{tabular}

*Different lowercase letters indicate statistically significant differences among the groups. $†$ Different uppercase letters indicate statistically significant differences between $\mathrm{CaF}_{2}$ formed or $\mathrm{CaF}_{2}$ retained (non paired $t$ test, $\mathrm{p}<0.05$ ). $\ddagger \mathrm{ANOVA}, \mathrm{p}<0.05$. $\S$ Kruskal-Wallis, $\mathrm{p}<0.05$.

TABLE 2- Amount of $\mathrm{F}(\mu \mathrm{g})$ detected in the solutions after $\mathrm{pH}$ cycling (mean \pm standard error)

\begin{tabular}{lrrrr}
\hline Group & DE1 & RE1 & DE2 & RE2 \\
\hline Placebo & $1.51 \pm 0.03^{\mathrm{a}}$ & $1.05 \pm 0.01^{\mathrm{a}}$ & $1.37 \pm 0.01^{\mathrm{a}}$ & $0.61 \pm 0.01^{\mathrm{a}}$ \\
Dura & $5.69 \pm 0.24^{\mathrm{b}}$ & $2.16 \pm 0.04^{\mathrm{b}}$ & $2.26 \pm 0.03^{\mathrm{b}}$ & $0.69 \pm 0.01^{\mathrm{b}}$ \\
Dura+coat & $3.41 \pm 0.05^{\mathrm{c}}$ & $2.47 \pm 0.08^{\mathrm{c}}$ & $2.48 \pm 0.03^{\mathrm{c}}$ & $0.72 \pm 0.02^{\mathrm{b}}$ \\
Duo & $56.42 \pm 1.66^{\mathrm{d}}$ & $3.96 \pm 0.17^{\mathrm{d}}$ & $3.29 \pm 0.17^{\mathrm{d}}$ & $0.93 \pm 0.01^{\mathrm{c}}$ \\
Duo+coat & $17.93 \pm 2.10^{\mathrm{e}}$ & $6.70 \pm 0.04^{\mathrm{e}}$ & $4.26 \pm 0.21^{\mathrm{e}}$ & $1.01 \pm 0.03^{\mathrm{c}}$ \\
\hline
\end{tabular}

Means followed by different letters indicate statistically significant difference between the groups (Kruskal-Wallis, $\mathrm{p}<0.05)$.

concentration in the products ${ }^{19}$, and it is very important for the efficacy of fluoride varnishes.

The fact that Duofluorid XII ${ }^{\mathrm{TM}}$ has twice the F concentration of Duraphat ${ }^{\mathrm{TM}}$ certainly contributed to the highest amounts of $\mathrm{CaF}_{2}$-like material observed in Duo and Duo+coat groups, which is probably originated from the pure $\mathrm{CaF}_{2}$ present in Duofluorid XII ${ }^{\mathrm{TM}}$. This may also explain the shallower the lesion depth $(\Delta \mathrm{Z})$ and the higher amount of $\mathrm{F}$ in all solutions analyzed for the groups Duo and Duo+coat when compared to Dura and Dura + coat. Another reason for these results is the fact that the synthetic resin base of Duofluorid XII ${ }^{\mathrm{TM}}$ makes the varnish less viscous and dense, which leads to a higher ability to release $\mathrm{F}$ in their matrixes ${ }^{7,20}$.

Analyzing the $\mathrm{F}$ released in the solutions and the $\mathrm{CaF}_{2}$ in enamel, an overall $\mathrm{F}$ kinetics during the $\mathrm{pH}$ cycling is observed. The $\mathrm{F}$ that was not released to the solutions during the first $6 \mathrm{~h}$ of $\mathrm{pH}$-cycling (when the coat was present) contributed to the formation of $\mathrm{CaF}_{2}$.

When the varnishes were removed the groups that received the coat treatment showed a higher amount of $\mathrm{F}$ released in "RE 1" because more $\mathrm{CaF}_{2}$ was formed on the enamel. With this observation, it may be assumed that $\mathrm{CaF}_{2}$ was readily loss to the medium as soon as the coat was removed in spite of the higher amount of $\mathrm{CaF}_{2}$ formed in the presence of the coat. This event may have contributed to the lack of efficacy of the coat regarding \% SMHC and $\Delta \mathrm{Z}$. This observation is also confirmed by the high release of F for the coat groups in "DE 2". Still, the coat did not influence the amount of $\mathrm{F}$ released in the last two days of pH-cycling ("RE2”).

The loss of $\mathrm{CaF}_{2}$ after treatment is in agreement with other studies. Attin, et al. ${ }^{2}$ found that $\mathrm{F}$ is leached away within the experimental period after a topical application of Bifluorid 12 ${ }^{\mathrm{TM}}$ (Voco Gmbh, Cuxhaven, Germany) or Duraphat ${ }^{\mathrm{TM}}$. Another interesting finding of the present study was that $\mathrm{CaF}_{2}$ retained was higher than $\mathrm{CaF}_{2}$ formed only in the placebo groups. This can be attributed to the $\mathrm{pH}$ cycling model used in the present study, which had a high acid challenge. The dental enamel becomes more reactive as enamel demineralization increases, which could have facilitated the deposition of $F$ from the solutions, even if it was present at low concentrations.

Moreover, the presence of the coat was not able to improve either $\% \mathrm{SMHC}$ or $\Delta \mathrm{Z}$ possibly because the amount of $\mathrm{CaF}_{2}$ was not high enough to induce a sensible change in enamel demineralization. It is probably necessary very high differences of $\mathrm{CaF}_{2}$, such as that observed between Duraphat and Duofluorid to detect changes in lesion depth or even higher amounts to show changes in surface microhardness.

F varnish can be clinically applied to prevent proximal caries $^{22}$, enamel demineralization during orthodontic treatment ${ }^{8}$, early childhood caries ${ }^{13}$. Prevention of proximal caries by $\mathrm{F}$ varnishes showed better results compared to fluoride mouthrinsing and the cost-effectiveness ratio observed was $1.8^{22}$. Due to the wide variety of clinical 
applications and the effectiveness of $\mathrm{F}$ varnishes, new products are constantly developed. Recently, two new F varnishes, including a bioerodible material, has been evaluated ${ }^{4,16}$ and showed good results.

\section{CONCLUSION}

It may be concluded that the application of the experimental coat reduced the amount of $\mathrm{F}$ released and increased the formation of $\mathrm{CaF}_{2}$, but it was not able to enhance the anticariogenic action of the $\mathrm{F}$ varnishes.

\section{ACKNOWLEDGEMENTS}

The authors thank FGM Produtos Odontológicos for supplying Duofluorid XII ${ }^{\mathrm{TM}}$ and the experimental coat. This work was supported by FAPESP (Grant \#04/00538-1).

\section{REFERENCES}

1- Arends J, ten Bosch JJ. Demineralization and remineralization evaluation techniques. J Dent Res. 1992;71:924-8.

2- Attin T, Hartmann O, Hilgers RD, Hellwig E. Fluoride retention of incipient enamel lesions after treatment with a calcium fluoride varnish in vivo. Arch Oral Biol. 1995;40:169-74.

3- Bawden JW. Fluoride varnish: a useful new tool for public health dentistry. J Public Health Dent. 1998;58:266-9.

4- Berg J, Riedy CA, Tercero A. Patient and parental perception of a new fluoride varnish. Compend Contin Educ Dent. 2006;27:614-8.

5- Bruun $\mathrm{C}$, Givskov H. Formation of $\mathrm{CaF}_{2}$ on sound enamel and in carieslike enamel lesions after different forms of fluoride applications in vitro. Caries Res. 1991;25:96-100.

6- Caslavska V, Moreno EC, Brudevold F. Determination of the calcium fluoride formed from in vitro exposure of human enamel to fluoride solutions. Arch Oral Biol. 1975;20:333-9.

7- Castilllo JL, Milgron P, Kharasch E, Izutsu K, Fey M. Evaluation of the fluoride release from commercially available fluoride varnishes. J Am Dent Assoc. 2001;132:1389-92.

8- Farhadian N, Miresmaeili A, Eslami B, Mehrabi S. Effect of fluoride varnish on enamel demineralization around brackets: an in-vivo study. Am J Orthod Dentofacial Orthop. 2008;133(4 Suppl):95-8.

9- Featherstone JD, ten Cate JM, Shariati M, Arends J. Comparison of artificial caries-like lesions by quantitative microradiography and microhardness profiles. Caries Res. 1983;17:385-91.

10- Fejerskov O, Ekstrand J, Burt BA. Fluoride in dentistry. Munksgaard: Copenhagen; 1996.

11- Hawkins R, Locker D, Noble J, Kay EJ. Prevention. Part 7: professionally applied topical fluorides for caries prevention. $\mathrm{Br}$ Dent $\mathrm{J}$. 2003;195:313-7.
12- Jeevarathan J, Deepti A, Muthu MS, Rathna Prabhu V, Chamundeeswari GS. Effect of fluoride varnish on Streptococcus mutans counts in plaque of caries-free children using dentocult SM strip mutans test: a randomized controlled triple blind study. J Indian Soc Pedod Prev Dent. 2007;25:157-63.

13- Lawrence HP, Binguis D, Douglas J, McKeown L, Switzer B, Figueiredo R, et al. A 2-year community-randomized controlled trial of fluoride varnish to prevent early childhood caries in aboriginal children. Community Dent Oral Epidemiol. 2008;36:503-16.

14- Maas JRS, Faraco IM Jr, Raupp SM, Hirata E, Delbem ACB. Differences in $\mathrm{CaF}_{2}$-like formation and anticariogenic activity in fluoridated resin based varnishes [abstract Pa177]. Braz Oral Res. 2004;18(Suppl):133. Presented at $21^{\text {nd }}$ Annual SBPqO Meeting; 2004; Águas de Lindóia, SP.

15- Marinho VC, Higgins JP, Logan S, Sheiham A. Fluoride varnishes for preventing dental caries in children and adolescents. Cochrane Database Syst Rev. 2002;3:CD002279.

16- Mazzawi JM, Henson T, Donly KJ. Inhibition of enamel demineralization by a bioerodible fluoridated resin. Am J Dent. 2007;20:134-6.

17- Miller EK, Vann WF Jr. The use of fluoride varnish in children: a critical review with treatment recommendations. J Clin Pediatr Dent. 2008;32:259-64

18- Øgaard B, Rölla G, Arends J. In vivo progress of enamel and root surface lesions under plaque as a function of time. Caries Res. $1988 ; 22: 302-5$

19- Saxegaard E, Rölla G. Fluoride acquisition on and in human enamel during topical application in vitro. Scand J Dent Res. 1988;96:523-35.

20- Shen C, Autio-Gold JT. Assessing fluoride concentration uniformity and fluoride release from three varnishes. J Am Dent Assoc. 2002;133:17682 .

21- Sköld L, Sundquist B, Eriksson B, Edeland C. Four-year study of caries inhibition of intensive Duraphat application in 11-15-year-old children. Community Dent Oral Epidemiol. 1994;22:8-12.

22- Sköld UM, Petersson LG, Birkhed D, Norlund A. Cost-analysis of school-based fluoride varnish and fluoride rinsing programs. Acta Odontol Scand. 2008;66:286-92.

23- Strohmenger L, Brambilla E. The use of fluoride varnishes in the prevention of dental caries: a short review. Oral Dis. 2001;7:71-80.

24- Vieira AE, Delbem AC, Sassaki KT, Rodrigues E, Cury JA, Cunha RF. Fluoride dose response in $\mathrm{pH}$-cycling models using bovine enamel. Caries Res. 2005;39:514-20. 